\title{
Biochemical and physiological analysis in carrot seeds from different orders of umbels ${ }^{1}$
}

\author{
Análise fisiológica e bioquímica de sementes de cenoura provenientes de diferentes \\ ordens de umbelas
}

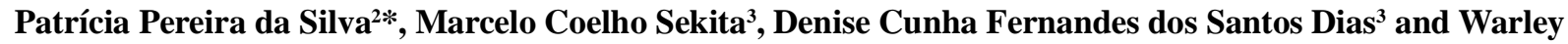 \\ Marcos Nascimento ${ }^{4}$
}

\begin{abstract}
In carrot seed production, harvesting of the umbels is generally staggered, or sometimes the whole plant is harvested with the umbels at different stages of maturation; in that case, there is a risk of harvesting immature seeds and of losses due to natural dehiscent, or to physiological deterioration as a result of unfavourable environmental factors. The present study aimed to evaluate the physiological and biochemical changes related to the maturation of 'Planalto' carrot seeds from diferent umbels. The samples were collected 120 days after anthesis, with the primary, secondary and tertiary umbels being harvested separately. Seeds were analysed for germination, first count and germination rate, at temperatures of $25^{\circ} \mathrm{C}$ (optimum) to $35^{\circ} \mathrm{C}$ (adverse), as well as for emergence in the greenhouse and the emergence rate. Analyses were also carried out of the enzymes peroxidase (POX), ascorbate peroxidase (APX), catalase (CAT) and superoxide dismutase (SOD), and of the total protein. Seeds obtained from the primary and secondary umbels displayed a higher rate of germination than from the tertiary umbels, with the seeds from the primary umbels showing high activity for peroxidase, catalase and superoxide dismutase, and low activity for the enzyme ascorbate peroxidase.
\end{abstract}

Key words: Daucus carota L.. Physiological quality. Enzyme activity.

\begin{abstract}
RESUMO - Na produção de sementes de cenoura, a colheita das umbelas é geralmente parcelada ou, em algumas vezes, colhe-se a planta toda com umbelas em diferentes estádios de maturação; nesse caso, corre-se o risco de colheita tanto de sementes imaturas como de ocorrerem perdas devido à debulha natural ou por deterioração fisiológica em consequência de fatores ambientais desfavoráveis. O presente estudo teve como objetivo avaliar as alterações fisiológicas e bioquímicas relacionadas à maturação das sementes de cenoura cv. Planalto provenientes de diferentes umbelas. As colheitas foram realizadas aos 120 dias após a antese, onde foram colhidas umbelas primárias, secundárias e terciárias separadamente. Sementes foram analisadas quanto a: germinação, primeira contagem e índice de velocidade de geminação nas temperaturas de $25^{\circ} \mathrm{C}$ (ótima) e $35^{\circ} \mathrm{C}$ (adversa), além de emergência em casa de vegetação e índice de velocidade de emergência. Foram ainda realizadas análises das enzimas peroxidase (POX), ascorbato peroxidase (APX), catalase (CAT) e superóxido dismutase (SOD), além das proteínas totais. As sementes obtidas das umbelas primárias e secundárias apresentaram germinação superior às sementes das umbelas terciárias, sendo que as sementes das umbelas primárias apresentaram elevada atividade de enzimas peroxidase, catalase e superóxido dismutase e baixa atividade da enzima ascorbato peroxidase.
\end{abstract}

Palavras-chave: Daucus carota L.. Qualidade fisiológica. Atividade enzimática.

\footnotetext{
DOI: $10.5935 / 1806-6690.20160049$

*Autor para correspondência

${ }^{1}$ Recebido para publicação em 16/05/2014; aprovado em 18/11/2015

Pesquisa financiada pelo $\mathrm{CNPq}$

${ }^{2}$ Departamento de Ciência e Tecnologia de Sementes, Universidade Federal de Pelotas, Av. Eliseu Maciel s/n, Campus Universitário de Capão do Leão, Pelotas-RS, Brasil, 96.900-900 patricia.pereira@colaborador.embrapa.br

${ }^{3}$ Departamento de Fitotecnia, Universidade Federal de Viçosa, Viçosa-MG, Brasil, marcelosekita@yahoo.com.br, dcdias@ufv.br

${ }^{4}$ Embrapa Hortaliças, Caixa Postal 280, Brasília-DF, Brasil, 70.359-970, warley.nascimento@embrapa.br
} 


\section{INTRODUCTION}

During flowering, the carrot plant (Daucus carota L.) emits a primary floral stem containing a central inflorescence at the apex, known as the primary umbel, which in turn branches into secondary, tertiary and quaternary umbels. The seeds produced in the different orders of umbels differ in physiological quality due mainly to uneven maturation (GOMES et al., 2012; NASCIMENTO, 1991). For seed production, staggered harvesting of the umbels based on visual characteristics is generally adopted, it still being possible to harvest the whole plant when the tertiary umbel has matured (SOARES, 2009).

It is therefore necessary to determine at which point carrot seeds mature, in order to avoid quantitative losses from dehiscent, and qualitative losses due to a susceptibility to physiological deterioration as a consequence of adverse environmental factors. It is known that with seed physiological maturity, there is a tendency towards a reduction in physiological quality, where the deterioration rate is influenced by environmental factors, especially those predominant during the final stage of maturation (PEDROSO et al., 2008). Among the changes caused by this deterioration, the most important are the degradation and inactivation of enzymes (TAIZ; ZEIGER, 2006), a reduction in the respiration rate (FERGUSON; TEKRONY; EGLI, 1990) and the loss of cell membrane integrity (TAIZ; ZEIGER, 2006). As the membranes consist of a lipid bilayer, they are the primary site for the process of lipid peroxidation, which leads to the production of free radicals, with disorganisation of the membrane system and a decline in seed vigour (MCDONALD, 1999).

According to Vangronsveld and Clijsters (1994), this oxidative stress is defined as a set of physiological changes caused by the direct or indirect action of ROS (reactive oxygen species), affecting such metabolic processes as respiration, the fixation of $\mathrm{CO}_{2}$ and gas exchange, among others. The excessive production of ROS, such as hydrogen peroxide $\left(\mathrm{H}_{2} \mathrm{O}_{2}\right)$, the superoxide radical $(\mathrm{O} 2)$ and the hydroxyl radical $(\mathrm{OH})$ may cause damage to seeds. These chemical reactions, which cause oxidative changes in cells (MOLLER JÉNSEN; HANSSON, 2007), contribute to increase the percentage of mutations (TAIZ; ZEIGER, 2006). The cells, however, have a complex system of defence to protect against damage caused by deterioration. This mechanism involves a set of antioxidant enzymes that catalyse the formation and regeneration reactions of molecules for the capture of ROS, or that are directly involved in their removal (MARTINS; MOURATO, 2008). The system that makes up this enzymatic mechanism associated with seed deterioration, is composed of several enzymes including peroxidase, ascorbate peroxidase, catalase and superoxide dismutase.

The major studies into seed maturation, including carrot, are related to monitoring the physiological changes that take place throughout the maturation process, such as germination and vigour. Information related to changes in the activity of enzymes during seed development and maturation remains scarce. Changes in the profiles of these enzymes are very important tools in monitoring the biochemical changes which result from deterioration, and which may occur during seed maturation and especially in the final stage of development, as oxidative processes tend to increase during water loss (OLIVER; BEWLEY, 1997). The function of these enzymes is to prevent the accumulation of toxic substances that are generated during oxidation. The aim of this study was to evaluate physiological and biochemical changes in 'Planalto' carrot seeds, harvested from different umbel orders.

\section{MATERIAL AND METHODS}

'Planalto' carrot seeds were produced were used, produced in the experimental area of Embrapa Hortaliças, Brasilia, from March to August of 2012, and harvested 120 days after anthesis, when 10 primary umbels, 15 secondary umbels and 20 tertiary umbels were harvested at random. After manual conditioning, seeds were submitted to physiological quality tests at the Seed Laboratory of Embrapa Hortaliças in Brasilia, and enzymatic analysis at the Seed Laboratory of the Federal University of Viçosa, in the State of Minas Gerais.

Germination test - using four replications of 50 seeds per treatment. The seeds were sown on germination paper moistened with distilled water at a ratio of 2.5 times the weight of the dry paper. The seeds were then incubated in BOD chambers at two temperatures: $25^{\circ} \mathrm{C}$ (optimal) and $35^{\circ} \mathrm{C}$ (adverse). Counts were taken 14 days after setting up the test. The results were expressed as a percentage (BRASIL, 2009).

First count - was carried out together with the germination test, counting the number of normal seedlings on the seventh day after the beginning of the test. The results were expressed as a percentage (BRASIL, 2009).

Germination rate - was held at the same time as the germination test, where daily counts were made using the formula described by Edmond and Drapala (1958). 
Seedling emergence in the greenhouse - using four replications of 100 seeds, which were sown in multicellular expanded-polystyrene trays of 200 cells containing commercial substrate. Irrigation was carried out daily. The evaluation was made 15 days after sowing, and the results expressed as a percentage.

Emergence rate - was obtained from daily counts of the germinated seedlings. Counts were taken until germination stabilised, i.e. 15 days after sowing, and the index calculated as per Edmond and Drapala (1958).

Thousand-seed weight - eight sub-samples of 100 dry seeds from each treatment were weighed, with the mean value of the results being expressed in grams (BRASIL, 2009).

Enzymatic analysis - initially, crude enzyme extract was obtained from the seeds to determine enzyme activity. The extract was obtained by the homogenisation of $0.3 \mathrm{~g}$ of seeds from each treatment using a mortar, in $2.0 \mathrm{ml}$ of $0.1 \mathrm{M}$ potassium phosphate buffer, $\mathrm{pH} 6.8$, supplemented with $50 \mathrm{mg}$ of PVPP (polyvinyl polypyrrolidone). The homogenate was then centrifuged at $12,000 \mathrm{xg}$ for 15 minutes at $4{ }^{\circ} \mathrm{C}$, and the supernatant collected and reserved in an ice bath. Determination of the enzyme ascorbate peroxidase (APX) was based on the oxidation of ascorbate 60 in the reaction for enzyme peroxidase activity. The enzyme peroxidase (POX) was determined with the spectrophotometric method, which measures the oxidation of guaiacol in the presence of hydrogen peroxide at a wavelength of $420 \mathrm{~nm}$. Catalase (CAT) activity was determined by the amount of enzyme needed to catalyse the decomposition of $\mathrm{H}_{2} \mathrm{O}_{2}$. Determination of the activity of superoxide dismutase (SOD) considered the enzyme's ability to inhibit the photo reduction of NBT (nitroblue tetrazolium chloride).

The total soluble protein content of the samples was determined by the Coomassie Brilliant Blue G dye method. The analysis was carried out in triplicate, using a test tube with $5 \mathrm{ml}$ of the reactive and adding $100 \mathrm{~mL}$ of crude extract. This was then agitated and after 15 minutes a reading was taken of the absorbance at $595 \mathrm{~nm}$. Bovine serum albumin solution (BSA, Sigma) was used as a standard, from which the standard curve was obtained over a concentration range of from 0 to $1 \mathrm{mg} \mathrm{mL}^{-1}$, with the protein concentration in the samples being determined by interpolation of the standard curve.

Experimental design and statistical analysis - the experimental design was completely randomised with four replications. Data for the parameters relating to seed physiological quality (expressed in percentage germination, first count and field emergence) were transformed by arcsine transformation $(x / 100)^{1 / 2}$. This data, together with the data relating to enzymatic activity, were subjected to analysis of variance, and the mean values compared by Tukey's test at $5 \%$ probability.

\section{RESULTS AND DISCUSSION}

When analysing the parameters of germination and vigour, seeds from the primary and secondary umbels showed superior physiological quality compared to seeds from the tertiary umbels at the two temperatures (Figures 1 and 2). However, there was a decrease in germination

Figure 1 - Results of the tests for first count, germination and germination rate (GR) at a temperature of $25{ }^{\circ} \mathrm{C}$ in seeds of 'Planalto' carrot from the primary (PU), secondary (SU) and tertiary (TU) umbels. Embrapa Hortaliças, Brasilia, 2014
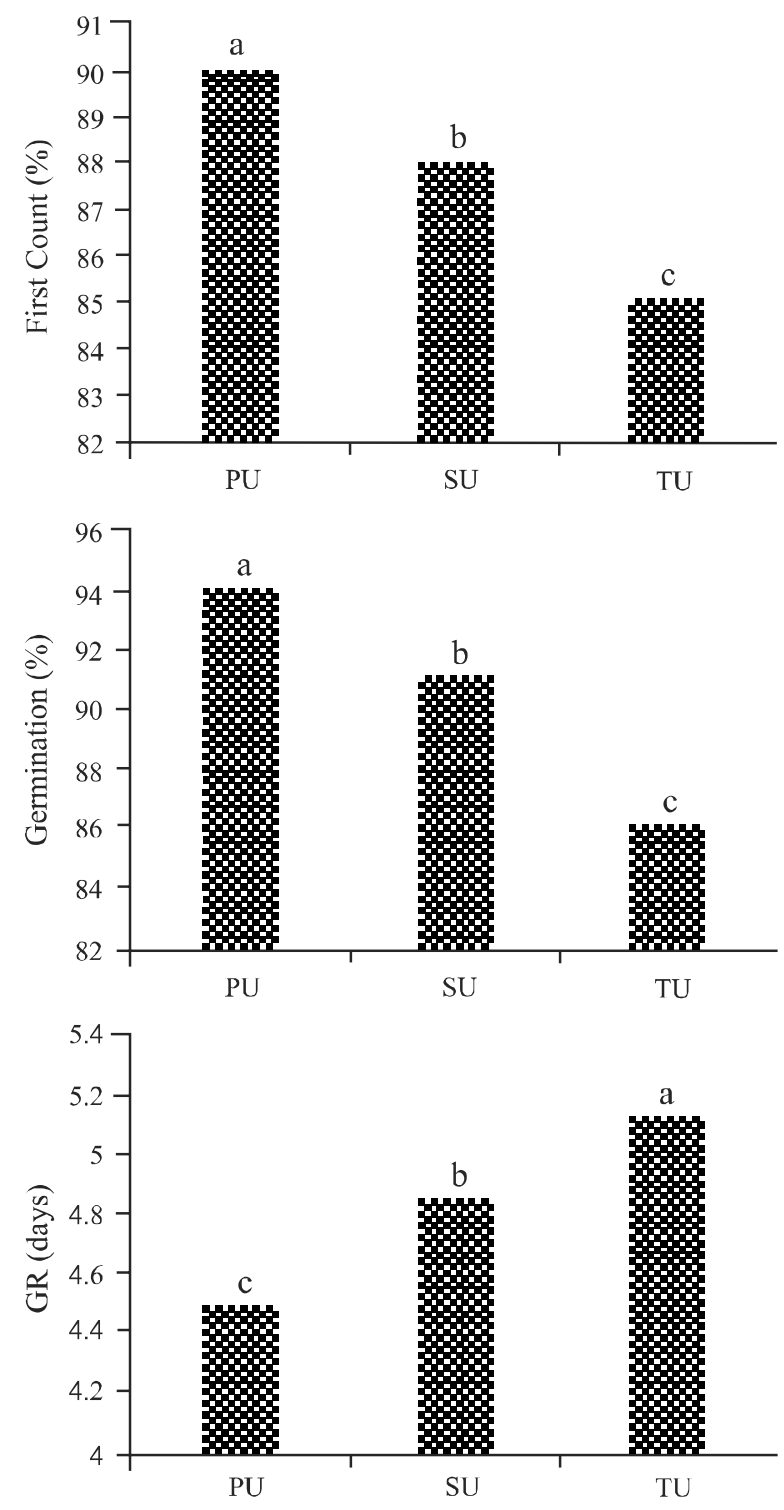
at high temperature; the percentage germination in seeds from the primary umbels was $94 \%$ at $25{ }^{\circ} \mathrm{C}$ and only $74 \%$ at $35^{\circ} \mathrm{C}$. This decrease in the germination of carrot seeds at high temperature was also found by Carneiro and Guedes (1992), where seeds of the 'Brasilia' carrot displayed $91 \%$ germination at $25{ }^{\circ} \mathrm{C}$, while germination decreased to $47 \%$ at $35{ }^{\circ} \mathrm{C}$.

Temperature is considered to be the factor with the most influence on the rate and percentage of

Figure 2 - Results of the tests for first count, germination and germination rate (GR) at a temperature of $35{ }^{\circ} \mathrm{C}$ in seeds of 'Planalto' carrot from the primary (PU), secondary (SU) and tertiary (TU) umbels. Embrapa Hortaliças, Brasilia, 2014
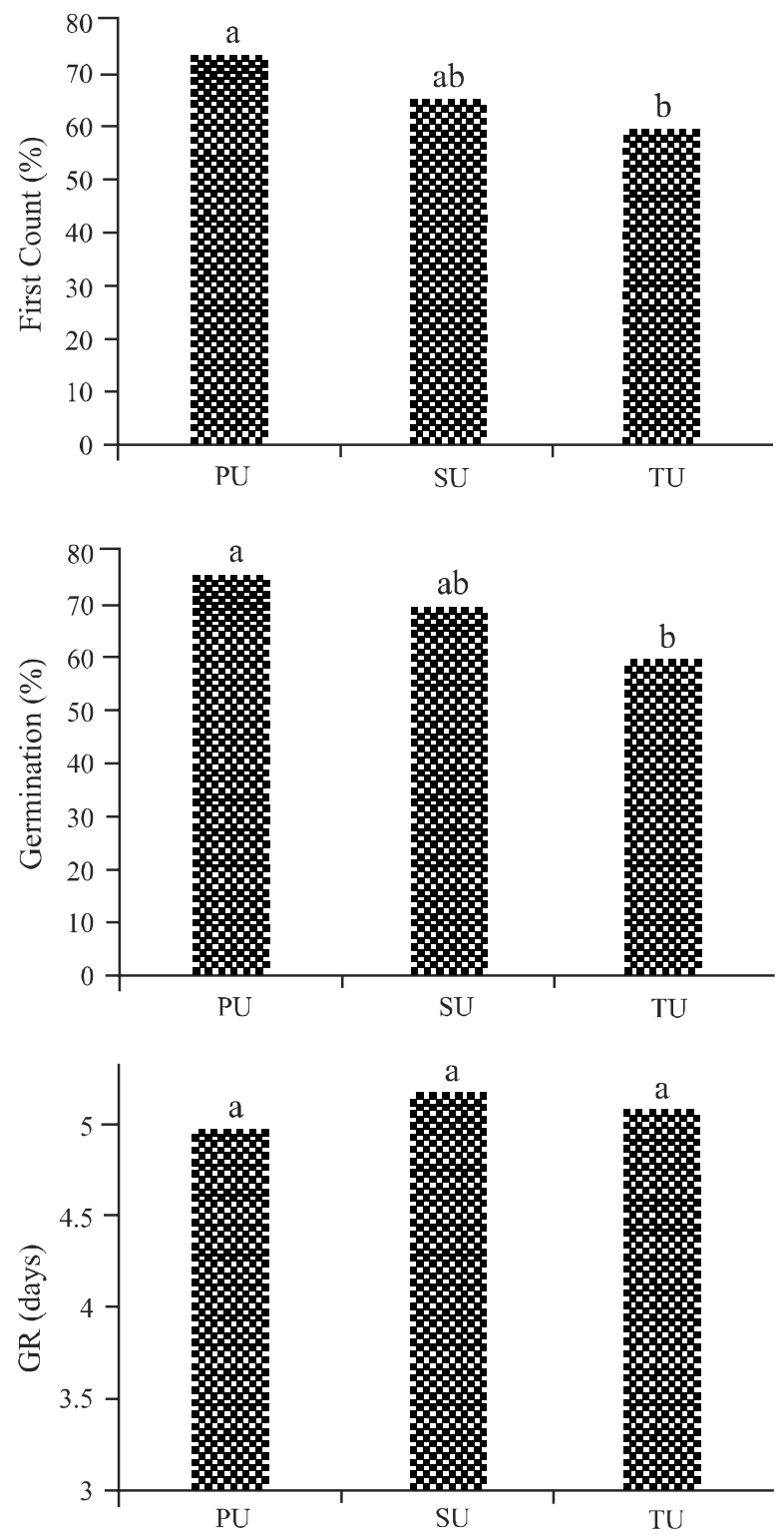

germination and emergence. High temperatures have a major influence on carrot seed germination, with some cultivars not germinating and others displaying dramatically reduced germination under such conditions (NASCIMENTO et al., 2008; PEREIRA; NASCIMENTO; VIEIRA, 2007).

Higher physiological quality was also seen in seeds from the primary and secondary umbels in the test for emergence in the greenhouse, and the emergence rate (Figure 3), achieving $76 \%$ and $58 \%$ emergence in seeds from the primary and secondary umbels respectively; in seeds from the tertiary umbels, emergence was only $47 \%$. Emergence rate revealed that the time required for the seeds to express their maximum capacity for germination was five days in seeds from the primary umbels, and seven days in seeds from the tertiary umbels. This result agrees with Pereira, Nascimento and Vieira (2008), who stated that seeds from the primary umbels display superior physiological quality when compared to the remaining orders.

Figure 3 - Results of the test for emergence in the greenhouse and emergence rate (ER) in seeds of 'Planalto' carrot from the primary (PU), secondary (SU) and tertiary (TU) umbels. Embrapa Hortaliças, Brasilia, 2014
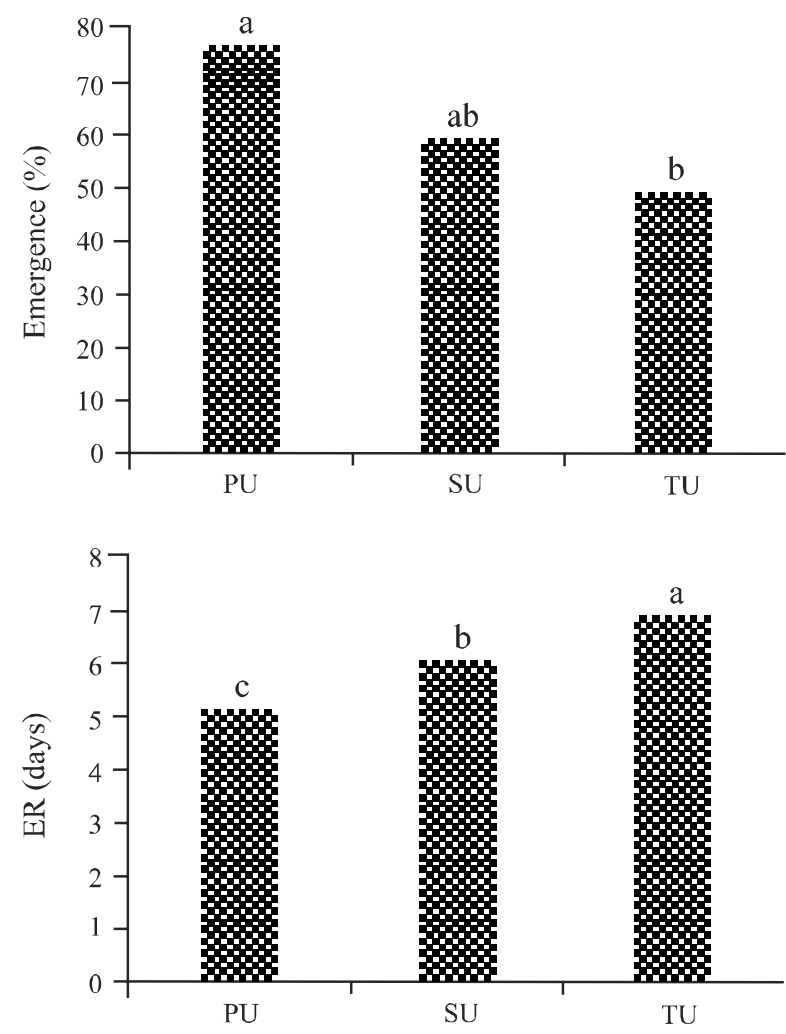
In analysis of the thousand-seed weight, 0.180; 1,162 and $1,150 \mathrm{~g}$ were obtained for the primary, secondary and tertiary umbels respectively. There is a tendency for the heavier seeds to show better physiological performance than the lighter seeds, resulting in better seedling development. This may probably be attributed to the fact that the composition of the heavier seeds has greater reserves per unit of dry matter (SANTOS et al., 2010). Furthermore, the right time for harvesting depends on the seed physiological maturity, which in many cases coincides with the maximum accumulation of dry matter. Also, when the seeds reach this stage, their germination potential and vigour increase (DUARTE; CARNEIRO, 2009). During maturation, changes in seed vigour occur in parallel with the transfer of plant dry matter to the seeds, i.e. the proportion of vigorous seeds increases with maturation, reaching a maximum very near to or at the same time as the maximum accumulation of reserves (MARCOS-FILHO, 2005).

The seeds from the different orders showed no differences in the concentration of soluble protein (Figure 4). The seed moisture content $(5.2 \%, 5.6 \%$ and $5.6 \%$ for the primary, secondary and tertiary umbels respectively), may favour reserve substances during development, possibly contributing to a higer protein concentration and therefore to germination. However, due to the little variation observed in the present study between the moisture levels of the different umbels, this was probably not the cause of these differences. It should be noted that the main function of the reserve proteins is the supply of amino acids for the formation of new proteins during germination (EICHELBERGER et al., 2002).

The enzyme POX is widely distributed in the cellular compartments, being associated with the cell walls, cell membranes, organelles, vacuoles and the cytosol (GILL; TUTEJA, 2010). The activity pattern of this enzyme was smaller in seeds from the secondary and tertiary umbels (Figure 4). The enzyme plays an important role in seed metabolism, contributing to an increase in defence mechanisms and preventing a loss in quality (CAMPOS et al., 2004), mainly by oxidizing a large variety of hydrogen-donor substances, such as phenols, aromatic-ring groups, diamines, ascorbic acid, and amino acids, besides certain inorganic ions by means of hydrogen peroxide $\left(\mathrm{H}_{2} \mathrm{O}_{2}\right)$ (CAVALCANTE et al., 2007).

On the other hand, APX, which is mainly found in the cytosol, and may be associated with the mitochondria, peroxisomes and apoplasts (ARORA; SAIRAM; SRIVASTAVA, 2002), displayed a decrease in activity in seeds from the primary and secondary umbels. The more intense activity of this enzyme in the early stages of the seed maturation process indicates that there was a higher demand for its defensive action for a reduction in superoxide, and a consequent reduction in the formation of free radicals, either as a result of the deterioration process or of seed immaturity. This also confirms the activity of the POX enzyme, where seeds from the tertiary umbels showed lower physiological quality when compared to seeds from the primary and secondary umbels.

Figure 4 - Total protein, peroxidase (POX) and ascorbate peroxidase (APX) activity in seeds of "Planalto' carrot from the primary (PU), secondary (SU) and tertiary (TU) umbels. Embrapa Hortaliças, Brasilia, 2014
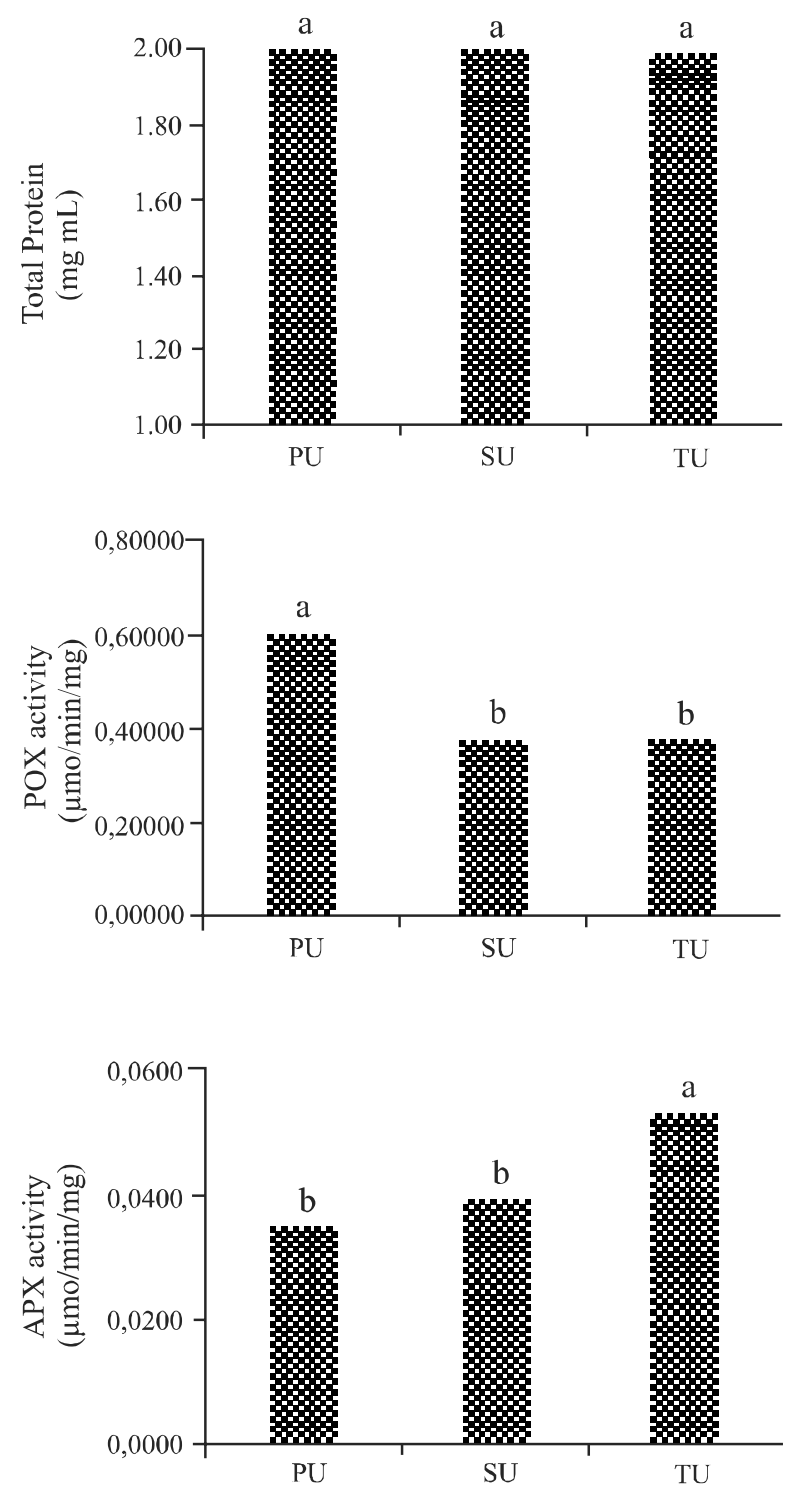
Figure 5 - Catalase (CAT) and superoxide dismutase (SOD) activity in seeds of "Planalto' carrot from the primary (PU), secondary (SU) and tertiary (TU) umbels. Embrapa Hortaliças, Brasilia, 2014
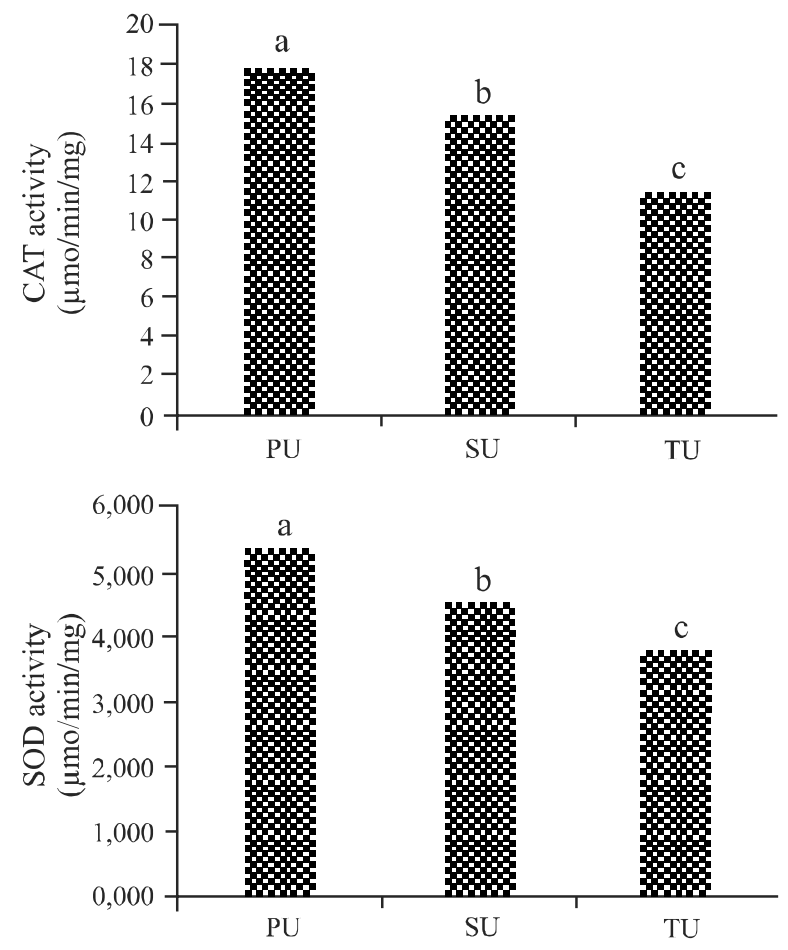

The results relating to the activity of the SOD enzyme (Figure 5) show a decrease in activity in seeds from the primary umbels. SOD is the first in the enzymatic barrier against oxidative stress, due to its action in the dismutation of $\mathrm{O}_{2}$, turning it into $\mathrm{H}_{2} \mathrm{O}_{2}+\mathrm{O}_{2}$ (GILL; TUTEJA, 2010; GRATÃO et al., 2005). It is found in different cellular compartments, such as the mitochondria, peroxisomes, the cytosol, and possibly in the extracellular space (ALSCHER; ERTURK; HEALTH, 2002).

An increase was also observed in the activity of the CAT enzyme in seeds from the primary umbels (Figure 5). Defence mechanisms are extremely important for the conservation of seed quality. Known as enzymatic systems, they are involved in the antioxidant response for neutralisation of singlet oxygen and other free radicals which are formed under conditions of stress (CONTRERASPORCIA et al., 2010; DUSSERT et al., 2006) such as occur during the drying process, for example.

In general, the seeds from tertiary umbels displayed lower physiological quality (germination and vigour) when compared to those from the primary and secondary umbels. A lower concentration of antioxidant enzymes was also found in the seeds from tertiary umbels, which probably led to the seeds not resisting the oxidative damage caused by exposure to drying.

\section{CONCLUSION}

The results obtained in this study support the conclusion that seeds derived from the primary and secondary umbels are of superior quality, possibly due to having a higher concentration of antioxidant enzymes.

\section{REFERENCES}

ALSCHER, R. G.; ERTURK, N.; HEALTH, L. S. Role of superoxide dismutases (SODs) in controlling oxidative stress in plants. Journal of Experimental Botany, Antioxidants and Reactive Oxygen Species in Plants, Special Issue, v. 53, n. 372, p. 1331-1341, 2002.

ARORA, A.; SAIRAM, R. K.; SRIVASTAVA, G. C. Oxidative stress and antioxidative system in plants. Current Science, v. 82, p. 1227-1238, 2002.

BRASIL. Ministério daAgricultura, Pecuária e Abastecimento. Secretaria Nacional de Defesa Agropecuária. Regras para análise de sementes. Brasília, 2009. 399 p.

CAMPOS, A. D. et al. Atividade de peroxidase e polifenoloxidase na resistência do feijão à antracnose. Pesquisa Agropecuária Brasileira, v. 39, n. 7, p. 637-643, 2004.

CARNEIRO, J. W. P.; GUEDES, T. A. Influência da temperatura no desempenho germinativo de sementes de cenoura (Daucus carota L.), avaliada pela função de distribuição de Weibull. Revista Brasileira de Sementes, v. 14, p. 207-213, 1992.

CAVALCANTE, F. R. et al. Roots and leaves display contrasting oxidative response during salt stress and recovery in cowpea. Journal of Plant Physiology, v. 164, p. 591-600, 2007.

CONTRERAS-PORCIA, L. et al. Tolerance to oxidative stress induced by desiccation in Porphyra columbina (Bangiales, Rhodophyta). Journal of Experimental Botany, v. 62, p. 1815-1829, 2010.

DUARTE, E. F.; CARNEIRO, I. F. Qualidade fisiológica de sementes de Dyckia Goehringii Gross \& Rauh (Bromeliaceae) em função do estádio de maturação dos frutos. Bioscience Journal, v. 25, n. 3, p. 161-171, 2009.

DUSSERT, S. et al. Oxidative stress, phospholipid loss and lipid hydrolysis during drying and storage of intermediate seeds. Physiologia Plantarum, v. 127, p. 192-204, 2006.

EDMOND, J. B.; DRAPALA, W. J. The effects of temperature, sand and soil, and acetone on germination of okra seed. Proceedings of the American Society for Horticutural Science, v. 71, p. 428-434, 1958. 
EICHELBERGER, L. et al. Composição química de sementes de azevém em resposta ao retardamento da secagem e ao armazenamento. Pesquisa Agropecuária Brasileira, v. 37, n. 5, p. 693-701, 2002.

FERGUSON, J. M.; TEKRONY, D. M.; EGLI, D. M. Changes during early soybean seed and axes deterioration: II. Lipids. Crop Science, v. 30, n. 1, p. 179-182. 1990.

GILL, S. S.; TUTEJA, N. Reactive oxygen species and antioxidant machinery in abiotic stress tolerance in crop plants. Plant Physiology and Biochemistry, v. 48, n. 12, p. 909-930, 2010.

GOMES, T. A. R. et al. Influência do tamanho de sementes de cenoura na produtividade da cultura. Cerrado Agrociências, v. 3, p. 72-82, 2012.

GRATÃO, P. L. et al. Phytoremediation: green technology for the clean up of toxic metals in the environment. Brazilian Journal of Plant Physiology, v. 17, n. 1, p. 53-64, 2005.

MARCOS-FILHO, J. Fisiologia de sementes de plantas cultivadas. Piracicaba: FEALQ, 2005. 495 p.

MARTINS, L.; MOURATO, M. Alterações no metabolismo de plantas em meios contaminados por metais pesados: stresse oxidativo. Revista Agros, v. 8, n. 2, 2008.

McDONALD, M. B. Seed deterioration: physiology, repair and assessment. Seed Science and Technology, v. 27, n. 1, p. 177-237, 1999.

MOLLER, I. M.; JÉNSEN, P. E.; HANSSON, A. Oxidative Modifications to cellular components in plants. Annual Review of Plant Biology, v. 58, p. 459-81, 2007.

NASCIMENTO, W. M. Efeito da ordem das umbelas na produção e qualidade de sementes de cenoura. Revista Brasileira de Sementes, v. 13, p. 131-133, 1991.
NASCIMENTO, W. M. et al. Carrot seed germination at high temperature: effect of genotype and association with ethylene production. HortScience, v. 43, p. 1538-1543, 2008.

OLIVER, M. J.; BEWLEY, J. D. Desiccation tolerance of plant tissues: a mechanistic overview. Horticultural Reviews, v. 18, p. 171-213, 1997.

PEDROSO, D. C. et al. Qualidade fisiológica e sanitária de sementes de Zinnia elegans Jacq colhidas em diferentes épocas. Revista Brasileira de Sementes, v. 30, p. 164-171, 2008.

PEREIRA, R. S.; NASCIMENTO, W. M.; VIEIRA, J. V. Carrot seed germination and vigor in response to temperature and umbel order, Scientia Agricola, v. 65, n. 2, p. 145-150, 2008.

PEREIRA, R. S.; NASCIMENTO, W. M.; VIEIRA, J. V. Germinação e vigor de sementes de cenoura sob condições de altas temperaturas. Horticultura Brasileira, v. 25, p. 215-219, 2007.

SANTOS, V. J. et al. Qualidade fisiológica de sementes de cenoura classificadas por tamanho. Ciência Rural, v. 40, n. 9, p. 1903-1908, 2010.

SOARES, F. H. Revestimento, qualidade física e fisiológica de sementes de cenoura (Daucus carota L.) cv. Brasília. 2009. 85 f. Tese (Doutorado em Agronomia) - Faculdade de Ciências Agrárias e Veterinárias, Universidade Estadual Paulista "Júlio de Mesquita", Jaboticabal, 2009.

TAIZ, L.; ZEIGER, E. Energy and Enzymes. In: TAIZ, L.; ZEIGER, E. Plant Physiology. 4th ed. Sunderland: Sinauer Associates, 2006. chap. 2, p. 1-22.

VANGRONSVELD, J. H.; CLIJSTERS. Toxic effects of metals. In: FARAGO, M. E. (Ed.). Plants and the chemical elements: biochemistry, uptake, tolerance and toxicity. Weinheim, New York: VCH, 1994. p. 150-177. 